TITLE:

\title{
Prevalence of positive FDG-PET findings in patients with high CEA levels(Abstract_要旨)
}

\author{
$\operatorname{AUTHOR}(S):$
}

Suga, Tsuyoshi

\section{CITATION:}

Suga, Tsuyoshi. Prevalence of positive FDG-PET findings in patients with high CEA levels. 京都大学, 2011, 博士(医学)

ISSUE DATE:

2011-07-25

URL:

http://hdl.handle.net/2433/147339

RIGHT: 


\begin{tabular}{|l|l|l|l|}
\hline 京都大学 & 博士 (医学) & 氏 名 & 菅 剛 \\
\hline 論文題目 & $\begin{array}{c}\text { Prevalence of positive FDG-PET findings in patients with high CEA levels } \\
\text { (CEA 高值患者における FDG-PET 検查の陽性䛦断率の検討) }\end{array}$ \\
& &
\end{tabular}

（論文内容の要旨）

Carcinoembryonic antigen(CEA)は最も一般的に利用される腫瘍マーカーで あり、さまざまな腫瘍で、病期診断、転移再発診断、治療効果判定などの指標 となる。また一方で、悪性疾患と直接の関係を持たない病態でも CEA は上昇 しうる。このため CEA 上昇時には、原因病変の指摘が臨床的に重要である。 一方、 ${ }^{18} \mathrm{~F}$-フルオロデオキシグルコース $(\mathrm{FDG})$ を用いた陽電子断層撮像法(PET) 検查は臨床腫瘍学で広く用いられる画像診断法であり、糖代謝の克進を画像化 することで、病変の性状や広がりの評価に有用な情報を与える。これにより、 形態画像診断で診断の困難な病変を指摘しうることが知られている。血中 CEA 上昇時には、FDG-PET 検査が重要な情報を提供することが多いことが知られ るが、これをエビデンスとして示した研究はこれまで少ない。本研究は、 FDG-PET 検查陽性率と、CEA 值、悪性腫瘍の既往歴、および CEA 值の径時 的変動傾向等との関連について検討したものである。当施設で 2004 年 6 月よ り 2005 年 12 月までに施行された FDG-PET 検查のうち、 428 検查、373人に おいて、CEA 值が $5.0 \mathrm{ng} / \mathrm{ml}$ を越えていた。このうち、治療中であった 50 人、 検查後の経過観察が不十分な 12 人、FDG 投与時の血糖值が $200 \mathrm{mg} / \mathrm{dl}$ を超え ていた 8 人を除いた、303 人を解析対象とした。このうち 46 人は複数回の FDG-PET 検查を受診しており、これらの患者群については、初回検査を解析 対象とした。303 検査の目的のうち、病期診断が 81 例、再発検索が 150 例、 良悪性鑑別が 69 例、その他 3 例であった。最終診断は 147 検査で組織学的に、 156 検査で最低 6 ケ月の経過観察に基づき決定した。PET 画像は 2 名以上の専 問医の読影により、定性的に診断された。303人のうち、最終的には 232 人が 悪性疾患を有していた。患者ベースの感度、特異度、陽性適中率、陰性適中率、

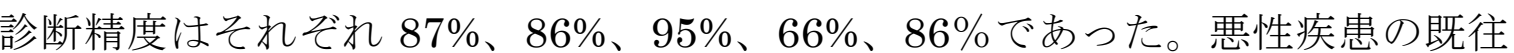
歴の有無は、PET 陽性率に有意な差をもたらさなかった。PET 陽性率は、CEA 值が高值となるにつれて有意に上昇傾向を示し、CEA が $20 \mathrm{ng} / \mathrm{ml}$ を越えた症例 では、90\%以上で陽性を示した。CEA 上昇傾向を示寸患者群では、減少傾向を 示す患者群に比較して有意に PET 陽性率が高く、CEA 值の doubling time が 長いほど、陽性率は低かった。CEA 高值の原因が PET 以前に不明な症例は 75 例あり、このうち最終的には 32 例が悪性腫瘍を有していたが、PET 検査の感 度は $59 \%$ であった。これらの症例においても、CEA 值が高值となるにつれて PET 陽性率は有意な上昇傾向を示した。今回の検討では CEA 高值であれば陽 性率が高く、既往の有無は陽性率に影響を示さなかったが、FDG 集積、CEA 值は、共に検査時の腫瘍細胞量と相関していると考えると、不思議ではない。 また、CEA 值上昇傾向を示寸症例では、腫瘍の増殖能が高いために、FDG 集 積六進が見られや寸くなると推測された。今回の検討において、PET 陽性適中 率は $95 \%$ と良好だったが、陰性適中率は $66 \%$ と比較的低い值に留まった。特 に病変が特定されていない場合、FDG 低集積となることが多い腫瘍に対して、
他法による検索も必要であると思われる。CEA 高值を示す症例に対しては、 PET 検査が高確率で陽性を示すことが期待される。この傾向は、過去の悪性腫 瘍の有無によらず、また、原因病変が不明の症例でも同様に認められる。

(論文審査の結果の要旨)

腺癌の指標となる癌胎児性抗原(CEA)は、悪性腫瘍のスクリーニング検査、治療後の経過 観察に用いられる腫瘍マーカーのひとつである。CEA 高值をみとめた場合は、画像診断 による病変の検索が必要となり、近年フルオロデオキシグルコース(FDG)を用いたボジト ロン断層撮像法(PET)検査が施行される機会が多い。しかしながら、CEA 高值の場合の PET 検查の有用性については十分なエビデンスが確立していない。本論文は CEA 高值の 際に施行された 303 人の PET 検査を振り返り、最終診断に基づいた悪性疾患の頻度、PET 検査の有所見率、感度、陽性的中率を調査寸るとともに、悪性疾患の既往の有無、CEA の経時変化との関連を検討したものである。悪性疾患の既往の有無、既往があった場合の 腫瘍の種類によらず、CEA の絶対值の増加につれて PET 検査の有所見率は増加し、10 $\mathrm{ng} / \mathrm{ml}$ 以上で $80 \%$ 以上、 $20 \mathrm{ng} / \mathrm{ml}$ 以上では $90 \%$ 以上の症例で陽性所見が得られ、いずれ の場合も感度、陽性啇中率は $90 \%$ 以上と良好な診断精度を有していた。連続的に CEA が 測定されていた症例では、増加群と減少群との間に有所見率の有意差は見られなかった が、CEA が 3ng/ml/100 日以上の増加率を示した群はそうでない群より有所見率が有意に 高かった。これらの結果に基づき、CEA が正常值 $(5 \mathrm{ng} / \mathrm{ml})$ 上限の 2 倍以上高值を示せば、 FDG-PET 検査による悪性腫瘍の検索を考慮して良いのではないかと考えられた。

以上の研究は PET 診断の適応の解明に貢献し、腫瘍の画像診断の進歩に寄与寸るところ が多い。

したがって、本論文は博士（医学 ）の学位論文として価值あるものと認める。

なお、本学位授与申請者は、平成 23 年 6 月 16 日実施の論文内容とそれに関連し た試問を受け、合格と認められたものである。 